\title{
SOKERIJUURIKKAAN KASVUKEHITYS VUOSINA 1950-1954 JA SADON ARVIOIMINEN KASVUKAUDELLA VIIKKO- NÄYTTEIDEN PERUSTEELLA
}

\author{
Aimo Kaivola \\ Turengin Sokeritehdas Oy, Turenki
}

Saapunut 15. 5. 1955.

Kasvinviljelyn pohjoisrajoilla kuten meillä, vaikuttavat sääolot suuresti sokerijuurikkaan sadon määrään ja laatuun. Sokerijuurikas on vaatelias yleensä kaikkien kasvutekijöiden suhteen ja etenkin silloin, kun sitä viljellään kasvukunnoltaan heikoilla mailla, voivat eri vuosina saatavat satotulokset suuresti vaihdella.

Juurikassokeritehtaalle, joka on raaka-aineen hankinnassaan kokonaan riippuvainen saatavasta sadosta, ja joka viljelysopimuksia tekemällä on sitoutunut vastaanottamaan määräalalta tulevan sadon, voivat suuret hehtaarisatojen heilahtelut aiheuttaa huomattavia vaikeuksia. Jotta voitaisiin tehdä välttämättömiä ennakkolaskelmia, on tulevan sadon arvioiminen jo kasvukaudella tarpeellista.

Kokemuksen mukaan ei pelkkä silmämääräinen sadonarviointi anna sokerijuurikkaalla hyvää tulosta, koska naatin ja juuren painosuhde on eri vuosina hyvinkin erilainen ja juuren keskipainon arvioiminen silmävaraisesti muutaman maasta vedetyn juurikkaan perusteella on vaikeata, johtuen kunkin yksilön erilaisesta koosta. Viikkonäytteiden antamia tuloksia hyväksikäyttäen voitaneen silmämääräisellä arvioinnilla päästä melko hyviin tuloksiin (2).

Juurikassokeritehtaat suorittavat useimmissa Länsi-Euroopan maissa sadon arviointia viikoittain otettujen näytteiden perusteella. Näytteenottomenetelmä ja näytteiden lukumäärä on eri maissa ja eri tehtaillakin erilainen.

Turengin Sokeritehtaalla on viikoittaisia kasvututkimuksia suoritettu melkein toiminnan alusta eli vuodesta 1948 lähtien. Kunakin vuonna odotettavissa olevan juurikassadon arvioimisen ohella on myös pyritty selvittämään sokerijuurikkaan juuren ja naatin kasvurytmiä sekä sokeripitoisuuden kehittymistä olosuhteissamme. Tämän tutkimusselostuksen puitteissa käsitellään vain vuosien 1950-1954 tuloksia, koska aikaisempien vuosien aineisto on verraten pieni ja tutkimus on aloitettu vasta syyskuun alussa. 


\section{Näytteenottomenetelmät}

Mainittujen viiden vuoden aikana on näytteiden otto aloitettu elokuun kolmannen viikon alkaessa ja lopetettu yleensä nostokauden päättyessä lokakuun loppupuolella. Näytteet on kerätty kasvukauden aikana valituilta tavallisilta juurikasmailta pyrkien löytämään kussakin neuvontapiirissä keskimääräistä kasvua edustavia maita. Tietyt käytännölliset seikat on näytteenottotiloja valittaessa ollut pakko huomioida. Mm. on tilat valittu jonkin sopivan kulkureitin varrelta. Viikkonäytteiden oton ovat suorittaneet tehtaan piirikonsulentit ja näytteet on välittömästi toimitettu tehtaalle. Aikaisempina vuosina juurikkaat tuotiin tehtaalle naatteineen. Vuosina 1953 ja 1954 on listiminen suoritettu jo pellolla ja naatit punnittu tavallisella käsipuntarilla. Tätä tapaa noudattaen saadaan tehtaalle tuleva näyte mahtumaan pienempään tilaan.

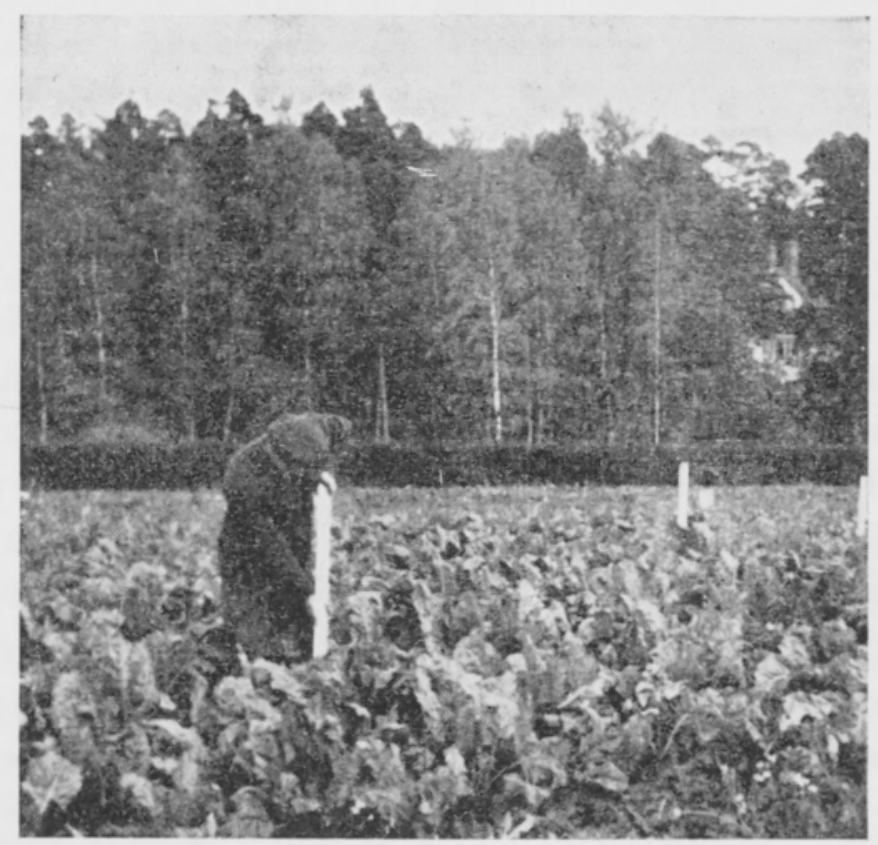

Kuva 1. Näytteenottokohdat merkitään paaluilla viikoittaisten kasvututkimusten alkaessa.

Abb. 1. Die Probenahmestellen werden mit Steckpfählen bezeichnet.

Ensimmäisinä vuosina näytteet otettiin elokuussa valitulta, pellon keskimääräistä kasvua edustavalta yhdeltä riviltä, johon lyötiin tarpeellinen määrä merkkipaaluja kahden metrin päähän toisistaan. Kullakin kerralla otettavan näytteen muodostivat kahden merkkipaalun välissä kahden metrin matkalla kasvavat juurikkaat. Tasaiselta, normaalisti harvennetulta riviltä piti näytteeseen tulla $7-9$ juurikasta. Käytännössä vaihteli juurikkaiden lukumäärä huomattavasti enemmän. Ottamalla näyte määrämatkalta yritettiin samalla määrittää kasvuston tiheys eli yksilöluku ko. juurikasmaalla. M€netelmä ei kummassakaan suhteessa täyttänyt toiveita.

Osoittautui välttämättömäksi lisätä juurikkaiden lukumäärää näytteissä. Vuonna 1952 kokeiltiin ns. linjamenetelmää, jossa kullakin näytteenottokerralla 
otettiin erikseen juurikasrivien poikki vedettävältä linjalta $15-20$ juurikasta. Menetelmä oli edellistä parempi antaen tasaisempia tuloksia, mutta ilmeisesti jätti liiaksi valintamahdollisuuksia näytteenottajalle.

Vuosina 1953 ja 1954 on noudatettu seuraavaa hyväksi todettua näytteenottomenetelmää. Juurikasmaalla merkitään edeltäkäsin noin metrin mittaisilla kepeillä viisi näytteenottokohtaa lyömällä keppi sopivalla kohdalla olevalle juurikasriville. Näytteenottokohdat sijoitetaan vinolinjaan poikki rivien tasaisten välimatkojen päähän. Kussakin näytekohdassa juurikkaat otetaan kepillä merkitystä sekä lähtökohdasta katsottuna sen oikealla puolella olevasta rivistä. Näistä kahdesta rivistä otetaan kumpaisestakin kaksi peräkkäin kasvavaa juurikasta eli yhteensä neljä juurikasta kustakin näytteenottokohdasta. Seuraavilla kerroilla jatketaan samoilla riveillä jättämällä yksi juurikas väliin nostamatta. Näytteeseen tulee kullakin kerralla tasan 20 juurikasta, jotka listitään pellolla ja naatit punnitaan käsipuntarilla.

Vuodesta 1951 lähtien on näytetilojen juurikasmaiden yksilöluku eli taimiluku laskettu 10 metrin mittaisilta havaintopätkiltä, joita on otettu noin $22 \mathrm{kpl}$ hehtaarilta eli noin $1 \%$ koko rivimetrimäärästä. Useampia hehtaareja käsittäviltä juurikasmailta on havaintopätkiä otettu suhteellisesti vähemmän. Taimien määrä hehtaarilta saadaan kertomalla edellämainittujen havaintotulosten keskiarvo 2.220:1lä. Tällöin on edellytetty rivivälin olevan $45 \mathrm{~cm}$ ja hehtaarin alalla siten 22.200 rivimetriä.

Havaintojen mukaan tulee keskimääräinen riviväli käytännössä yleensä edellä sanottua jonkinverran suuremmaksi. Vuosina 1953 - 54 onkin määritetty mittaamalla myös keskimääräinen riviväli, minkä perusteella voidaan tarkasti laskea hehtaarin alalla oleva rivimetrimäärä ja taimiluku. Samoin voidaan todellinen kasvullinen ala, jota käytetään hehtaarisatoja laskettaessa, määrittää tarkasti juurikasmaan rivimetrimäärän ja keskimääräisen rivivälin perusteella. Näin laskien saadaan myös avo-ojitetuilla mailla salaojitettua pinta-alaa vastaava kasvullinen ala.

Näytetiloja oli vuosina 1950 - 1952 koko Turengin tehtaan viljelyalueella vuosittain yhteensä 40 - $90 \mathrm{kpl}$. Vuosina 1953 - 54 on kussakin kahdessatoista neuvontapiirissä ollut 8 näytetilaa eli yhteensä 96 tilaa ja näytteet on pyritty saamaan kumpaisenakin vuonna samoilta tiloilta.

Kustakin näytteestä määritetään puhtaiden juurikkaiden keskipaino, sokeripitoisuus, siniluku ja tuhkaluku laboratoriossa sekä naatin keskipaino pellolla suoritetun punnituksen mukaan. Tässä tutkimusselostuksessa esitetään vain juuren ja naatin painoa sekä sokeripitoisuutta koskevat yhteenvedot.

\section{Kasvukausien 1950-1954 sääsuhteista}

Turengin Sokeritehtaan viljelyalue käsittää Hämeen ja Uudenmaan läänit. Oheisissa taulukoissa $1-2$ esitetään kasvukausien 1950-1954 keskilämpötilat ja sademäärät kuukausittain mainituissa lääneissä laskettuna poikkeamina normaaliarvoista Ilmatieteellisen Keskuslaitoksen kuukausikatsausten mukaan.

Tutkimuksen piiriin kuuluvista vuosista oli kasvukausi 1950 lämpöoloiltaan 
Taulukko 1. Keskilämpötiłojen poikkeamat normaaliarvoista kasvukausina 1950 - 1954 Turengin Sokeritehtaan viljelyalueella.

Tabelle 1. Abweichungen der Monatsmittel der Temperatur vom Normalwert in den Vegetationsperioden der Jahre 1950 - 1954 im Anbaugebiet der Zuckerfabrik in Turenki.

\begin{tabular}{|c|c|c|c|c|c|c|}
\hline $\begin{array}{l}\text { Hämeen lääni } \\
\text { (Tampere) } \\
\text { Län Häme }\end{array}$ & $\begin{array}{l}\text { Norm. } \\
\mathrm{C}^{\circ}\end{array}$ & 1950 & 1951 & 1952 & 1953 & 1954 \\
\hline $\begin{array}{l}\text { Toukokuu } \\
\text { Mai }\end{array}$ & 8.6 & +1.0 & -2.4 & -0.7 & +1.1 & $+3 . ?$ \\
\hline $\begin{array}{l}\text { Kesäkuu } \\
\text { Juni }\end{array}$ & 13.5 & +1.6 & -0.1 & -0.2 & +4.1 & -0.4 \\
\hline $\begin{array}{l}\text { Heinäkuu } \\
\text { Juli }\end{array}$ & 16.9 & -1.9 & -2.2 & -1.5 & -0.7 & -9.5 \\
\hline $\begin{array}{l}\text { Elokuu } \\
\text { August }\end{array}$ & 14.4 & +1.7 & +3.5 & -1.0 & -0.1 & +0.2 \\
\hline $\begin{array}{l}\text { Syyskuu } \\
\text { September }\end{array}$ & 9.8 & +0.8 & +1.7 & -2.0 & -1.0 & +0.4 \\
\hline $\begin{array}{l}\text { Lokakuu } \\
\text { Oktober }\end{array}$ & 4.2 & +0.7 & +1.5 & -3.1 & +2.7 & -0.1 \\
\hline $\begin{array}{c}\text { Uudenmaan lääni } \\
\text { (Helsinki) } \\
\text { Län Uusimaa }\end{array}$ & $\begin{array}{l}\text { Norm. } \\
\mathrm{C}^{\circ}\end{array}$ & 1950 & 1951 & 1952 & 1953 & 1954 \\
\hline $\begin{array}{l}\text { Toukokuu } \\
\text { Mai }\end{array}$ & 9.0 & +-0.9 & --1.2 & -1.5 & +0.1 & +2.1 \\
\hline $\begin{array}{l}\text { Kesäkuu } \\
\text { Juni }\end{array}$ & 13.5 & +1.0 & +0.2 & \pm 0.0 & +3.2 & -9.4 \\
\hline $\begin{array}{l}\text { Heinäkuu } \\
\text { Juli }\end{array}$ & 17.1 & -1.4 & -1.6 & -1.0 & \pm 0.0 & +0.4 \\
\hline $\begin{array}{l}\text { Elokuu } \\
\text { August }\end{array}$ & 15.2 & +1.7 & +3.2 & -0.8 & +0.4 & +0.6 \\
\hline $\begin{array}{l}\text { Syyskuu } \\
\text { September }\end{array}$ & 10.8 & +1.5 & +2.3 & -1.5 & -0.1 & +1.7 \\
\hline $\begin{array}{l}\text { Lokakuu } \\
\text { Oktober }\end{array}$ & 5.6 & +1.3 & +1.9 & -2.1 & +3.0 & +0.9 \\
\hline
\end{tabular}

suunnilleen normaali ja jonkinverran keskimäärää kuivempi. Seuraava kasvukausi oli erittäin kuiva ja loppukesä helteinen. Vuonna 1952 oli huomattavasti normaalia kylmempi kasvukausi. Vaikka sademäärät olivatkin suunnilleen normaalit, oli jatkuvasta pilvisyydestä ja vähäisestä haihtumisesta johtuen hyvinkin kosteata. Jo lokakuussa satoi niin paljon lunta, että naatit toisinaan olivat lumen alla ja pysyvä talvi tuli loka-marraskuun vaihteessa. Kasvukausi 1953 oli varsin suotuisa nimenomaan lämpimän kevään ansiosta. Heinäkuulta lähtien sademäärät olivat normaalia suurempia, mutta eivät näyttäneet vaikuttavan haitallisesti, koska välillä oli auringonpaisteisia päiviä ja lämpötila pysyi normaalina. Kasvukausi 1954 oli lämpösuh- 
Taulukko 2. Kasvukausien 1950-1954 sademäärien poikkeamat normaaliarvoista Turengin Sokeritehtaan viljelyalueella.

Tabelle 2. Abweichungen der mittleven Monatsniederschläge vom Normalwert in den Vegetationsperioden der Jahre 1950-1954 im Anbaugebiet der Zuckerfabrik in Turenki.

\begin{tabular}{|c|c|c|c|c|c|c|}
\hline $\begin{array}{c}\text { Hämeen lääni } \\
\text { Län Häme }\end{array}$ & $\begin{array}{l}\text { Norm. } \\
\mathrm{mm} \text {. }\end{array}$ & 1950 & 1951 & 1952 & 1953 & 1954 \\
\hline $\begin{array}{l}\text { Toukokuu } \\
\text { Mai }\end{array}$ & 45 & -6 & -20 & -9 & -6 & -28 \\
\hline $\begin{array}{l}\text { Kesäkuu } \\
\text { Juni }\end{array}$ & 58 & -28 & -27 & $\pm n$ & +7 & -20 \\
\hline $\begin{array}{l}\text { Heinäkuu } \\
J u l i\end{array}$ & 73 & -25 & -24 & +4 & +61 & +29 \\
\hline $\begin{array}{l}\text { Elokuu } \\
\text { August }\end{array}$ & 77 & -48 & -51 & +26 & +24 & +47 \\
\hline $\begin{array}{l}\text { Syyskuu } \\
\text { September }\end{array}$ & 67 & +36 & -28 & -13 & -19 & +24 \\
\hline $\begin{array}{l}\text { Lokakuu } \\
\text { Oktober }\end{array}$ & 67 & \pm 0 & -57 & +25 & -34 & +2 \\
\hline $\begin{array}{l}\text { Touko-syyskuu } \\
\text { Mai-September }\end{array}$ & 320 & -71 & -150 & +8 & +71 & +52 \\
\hline $\begin{array}{l}\text { Uudenmaan lääni } \\
\text { Län Cusimaa }\end{array}$ & $\begin{array}{l}\text { Norm. } \\
\mathrm{mm} \text {. }\end{array}$ & 1950 & 1951 & 1952 & 1953 & 1954 \\
\hline $\begin{array}{l}\text { Toukokuu } \\
\text { Mai }\end{array}$ & 46 & -17 & -38 & -17 & -6 & -34 \\
\hline $\begin{array}{l}\text { Kesäkuu } \\
\text { Juni }\end{array}$ & 51 & -25 & -10 & +6 & +16 & -12 \\
\hline $\begin{array}{l}\text { Heinäkuu } \\
\text { Juli }\end{array}$ & 66 & -9 & -18 & -13 & +34 & +37 \\
\hline $\begin{array}{l}\text { Elokuu } \\
\text { August }\end{array}$ & 83 & -54 & -52 & -1 & +5 & +27 \\
\hline $\begin{array}{l}\text { Syyskuu } \\
\text { September }\end{array}$ & 72 & +56 & -30 & +12 & +11 & +39 \\
\hline $\begin{array}{l}\text { Lokakuu } \\
\text { Oktober }\end{array}$ & 74 & +14 & -66 & +83 & -51 & -1.5 \\
\hline Touko-syyskuu & 318 & -49 & -148 & -13 & +60 & +57 \\
\hline
\end{tabular}

Mai-September

teiltaan suunnilleen normaali. Kuten yleensäkin viime vuosina oli myös ko. vuonna touko-kesäkuu hyvin kuiva, mutta heinäkuusta lähtien sademäärät olivat normaalia suurempia ja hyvin selviä liikamärkyydestä johtuvia haittoja alkoi ilmetä sokerijuurikaskasvustoissa jo elokuun lopulla.

Keskilämpötilat ja sademäärät kuvastavat sääsuhteita vain pääpiirteittäin. Varsin merkittäviä lisätekijöitä ovat mm. pilvisyys ja tuulisuus sekä se, millä tavoin 
sademäärä on maahan tullut. Pitkän, hiljaisen sateen kosteutta lisäävä vaikutus on aivan toinen kuin lyhyiden, suuriakin vesimääriä antavien kuurosateiden vaikutus.

Kasvukauden alkamisen ajankohdalla on erittäin suuri merkitys sokerijuurikkaalle, koska kasvupäiviä yleensä on meillä liian niukasti. Sokerijuurikkaan keskimääräisestä kylvöajasta Hämeessä ja Uudellamaalla on kirjoittajalla havaintoja vain vuosilta 1952 - 1954. Sokerijuurikkaan kylvötöiden alkamisen ajankohta näyttää yleensä tulevan vasta vesistöjen jäiden lähdön aikoihin tai sen jälkeen, siitä riippumatta, miten aikaisin lumi on maasta hävinnyt. Ilmatieteellisen Keskuslaitoksen kuukausikatsausten mukaan on jäiden lähtö Etelä-Suomen vesistöistä tapahtunut eri vuosina seuraavasti:

Vuosi Jäiden läht ö

1950 huhtikuun jälkipuoliskolla

1951 huhtikuun viimeisellä viikolla

1952 huhtikuun jälkipuoliskolla tai lopussa

1953 huhtikuun puolivälissä

1954 huhti-toukokuun vaihteessa tai toukokuun alussa.

Vuosina 1951 ja 1952 on sokerijuurikkaan kylvöt suoritettu suunnilleen toukokuun 5-10 päivän paikkeilla, v. 1950 huhti-toukokuun vaihteessa. Vuonna 1953 oli

Taulukko 3. Juuren ja naatin painon kehittyminen (grammoina) eri kasvukausina ja keskimäärin vuosina 1950-1954 Hämeessä ja Uudellamaalla.

Tabelle 3. Gewichtsentwicklung von Wurzel und Kraut der Zuckerrüben $(g)$ in den einzelnen Vegetationsperioden und durchschnittlich in der Zeit von 1950-1954 im Anbaugebiet der Zuckerfabrik in Turenki

\begin{tabular}{|c|c|c|c|c|c|c|c|c|c|c|c|c|c|}
\hline \multirow{2}{*}{$\begin{array}{l}\text { Tutk. } \\
\text { viikko } \\
\text { Woche }\end{array}$} & \multirow{2}{*}{$\begin{array}{c}\text { Kesłim. } \\
\text { päivä } \\
\text { Durch- } \\
\text { schn. } \\
\text { Datum }\end{array}$} & \multicolumn{2}{|c|}{1950} & \multicolumn{2}{|c|}{1951} & \multicolumn{2}{|c|}{1952} & \multicolumn{2}{|c|}{1953} & \multicolumn{2}{|c|}{1954} & \multicolumn{2}{|c|}{$1950-54$} \\
\hline & & $\begin{array}{c}\mathrm{J} \\
W\end{array}$ & $\begin{array}{l}\mathrm{N} \\
K r\end{array}$ & $\underset{W}{\mathrm{~J}}$ & $\begin{array}{c}\mathrm{N} \\
K r\end{array}$ & $\begin{array}{c}\mathrm{J} \\
W\end{array}$ & $\begin{array}{c}N \\
K r\end{array}$ & $\underset{W}{\mathrm{~J}}$ & $\begin{array}{c}\mathrm{N} \\
K r\end{array}$ & $\begin{array}{c}\mathrm{J} \\
W\end{array}$ & $\begin{array}{l}\mathrm{N} \\
K r\end{array}$ & $\frac{\mathrm{J}}{W}$ & $\begin{array}{l}\mathrm{N} \\
K r\end{array}$ \\
\hline I & 18. 8. & 170 & 300 & 149 & 303 & 187 & 529 & 268 & 607 & 172 & 614 & 189 & 471 \\
\hline II & 25.8 & 176 & 313 & 183 & 323 & 212 & 549 & 303 & 580 & 186 & 612 & 212 & 475 \\
\hline III & 1. 9. & 253 & 416 & 232 & 360 & 255 & 600 & 346 & 630 & 222 & 629 & 262 & 527 \\
\hline IV & 8. 9. & 285 & 452 & 255 & 360 & 325 & 627 & 366 & 619 & 252 & 624 & 297 & 536 \\
\hline V & 15. 9. & 290 & 451 & 270 & 376 & 321 & 576 & 375 & 593 & 305 & 698 & 312 & 539 \\
\hline VI & $22 . \quad 9$. & 311 & 466 & 305 & 402 & 332 & 652 & 382 & 604 & 318 & 648 & 330 & $5 \approx 4$ \\
\hline VII & 29. 9 & 356 & 471 & 315 & 420 & 356 & 652 & 418 & 598 & 339 & 632 & 357 & 555 \\
\hline VIII & 6. 10 & 351 & 482 & 320 & 400 & 348 & 651 & 455 & 563 & 346 & 575 & 364 & 534 \\
\hline IX & 13. 10. & 338 & 436 & 302 & 437 & 357 & 654 & 461 & 553 & 380 & 615 & 368 & 539 \\
\hline X & 20.10. & 332 & 390 & 311 & 393 & 351 & 676 & 488 & 547 & 377 & 559 & 372 & 513 \\
\hline \multicolumn{2}{|c|}{$\begin{array}{l}\text { Nostoajan } \\
\text { keskiarvot } \\
\text { Durchschn. } \\
\text { zur Erntezeit }\end{array}$} & 348 & 463 & 312 & 419 & 353 & 652 & 444 & 571 & 355 & 607 & 363 & 542 \\
\hline
\end{tabular}




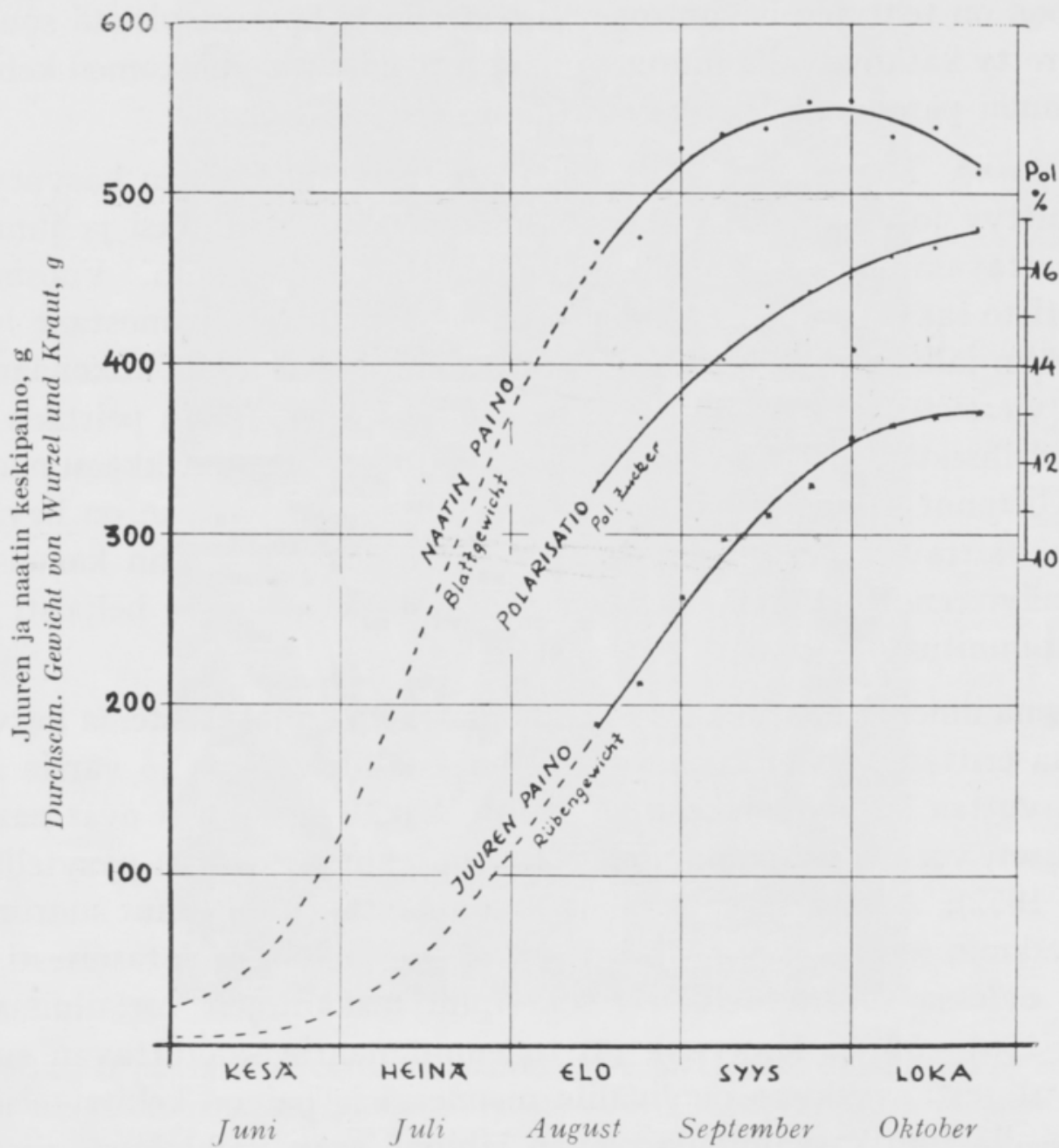

Piırros 1. Juuren ja naatin painon sekä sokeripitoisuuden kehittyminen keskimäärin kasvukausina $1950-1954$.

Fig. 1. Entwicklung des Gewichtes von Wurzel und Kraut sowie des Zuckergehalts durchschnittlich in den Vegetationsperioden der Jahre 1950-1954.

keskimääräinen kylvöpäivä Turengin tehtaan viljelyalueella 27. 4. ja v. 1954 13. 5. Kun nostoaika olosuhteiden pakosta muodostuu kaikkina vuosina suunnilleen samaksi, on sokerijuurikkaan kasvuaika aikaisena vuonna 1953 ollut lähes kolme viikkoa pidempi kuin myöhäisenä vuonna 1954 .

\section{Sokerijuurikkaan juuren ja naatin kasvu viikkonäytteiden mukaan}

Kuten aikaisemmin mainittiin, on viikkonäytteiden otto aloitettu elokuun kolmannen viikon alkaessa eli keskimäärin elokuun 18 päivänä. Kun näytteet on aina otettu maanantaisin, on päivämäärä eri vuosina jonkinverran siirtynyt. Oheisessa taulukossa 3, josta käy ilmi juuren ja naatin keskipaino viikoittain eri vuosina, on ilmoitettu keskimääräiset näytteenottopäivät. Taulukossa ja piirroksessa 1 on esitetty sokerijuurikkaan juuren ja naatin keskimääräinen kasvu vuosina 1950- 
1954. Kuvioon on tehtyjen havaintojen perusteella ja käyrien yleistä suuntaa noudattaen piirretty katkoviivalla juuren ja naatin painon todennäköinen kehitys myös kesä-heinäkuulla paremman yleiskuvan saamiseksi.

Naatin paino. Sokerijuurikkaalla on tunnetusti sentapainen kasvurytmi, että naatisto kehittyy jo aikaisessa vaiheessa huomattavan reheväksi ja juuren kasvu alkaa huomattavammin vasta melkein kuukautta myöhemmin. Vuosina 19501954 on naatisto saavuttanut keskimäärin puolet lopullisesta painostaan heti heinäkuun puolivälin jälkeen. Tässä vaiheessa alkaa juurikasmaa olla kokonaan naattien peitossa, ts. viereisten juurikasrivien naatit leviävät vastakkain peittäen 45 sentin rivivälin täydellisesti. Suurimman painonsa, noin $550 \mathrm{~g}$, on juurikkaan naatti keskimäärin saavuttanut syyskuun viimeisellä viikolla, minkä jälkeen on lievää painon laskemista havaittavissa. Sateisuuden vaihtelut ilmenevät naatin kasvussa varsin selvästi ja näytteenottohetkelle sattuva sade aiheuttaa myös helposti tilapäisiä heilahteluja punnitustuloksissa.

Eri vuosina ilmenee naatin kasvussa huomattavia eroja. Kosteina kasvukausina naatti kasvaa erittäin rehevästi ja voi myöhäisenäkin vuonna jo varsin aikaisessa vaiheessa saavuttaa huippupainonsa (v. 1954). Mikäli olosuhteet ovat naatin säilymiselle edulliset, voi naatin paino vielä lokakuullakin jatkuvasti pysytellä huipputasollaan (v. 1952). Aikaisena vuonna (1953) on naatti saavuttanut suurimman painonsa jo syyskuun alussa, mistä lähtien sen paino on hiljalleen tasaisesti laskenut. Etelämpänä Salossa suoritetuissa eri sokerijuurikaskantojen vertailuissa vuosina 1947-49 ja 1951-52 on MANTERE (4) todennut naatin saavuttavan suurimman painonsa tavallisesti syyskuun puoliväliin mennessä ja painon kehittymisen hyvinkin erityyppisillä juurikaskannoilla olevan lähinnä sään vaihteluista riippuvaisen. Naatin kasvu päättynee siis Salon seudulla keskimäärin noin viikkoa aikaisemmin kuin Hämeessä ja Uudellamaalla keskimäärin. Pääasiassa tähän vaikuttanee aikaisempi kylvö, mutta myös maalajilla on todennäköisesti vaikutusta jompaan kumpaan suuntaan. Hämeen ja Uudenmaan juurikasmaista on yli puolet tyypillisiä hietamaita, joilla naatti kehittyy huomattavasti rehevämmin kuin savimailla. Myös

Taulukko 4. Juurikkaan keskimääräinen kasvu vuosina 1950-1954.

Tabelle 4. Durchschnittliches Wachstum der Rübe in den Jahren 1950-1954

\begin{tabular}{|c|c|c|c|}
\hline $\begin{array}{l}\text { Päivämäärä } \\
\text { Datum }\end{array}$ & $\begin{array}{c}\text { Juuren keskipaino } \\
\text { Durchschn. Wurzelgewicht } \\
\mathrm{g}\end{array}$ & $\begin{array}{l}\text { Lisäkasvu } \\
\text { Zuwachs } \\
\text { g }\end{array}$ & $\begin{array}{c}\text { Kasvu, \% loppupainosta } \\
\text { Wachstum, \% vom } \\
\text { Endgewicht }\end{array}$ \\
\hline 1. 8. & 115 & - & $31 \%$ \\
\hline 1. 9 . & 262 & +147 & $71 \%$ \\
\hline 1. 10 . & 360 & $\begin{array}{l}+98 \\
\end{array}$ & $97 \%$ \\
\hline 20.10. & 372 & +12 & $100 \%$ \\
\hline $\begin{array}{l}\text { Nostoajan keskiarv } \\
\text { Wurzelgewicht zur }\end{array}$ & rntezeit & - & $98 \%$ \\
\hline
\end{tabular}




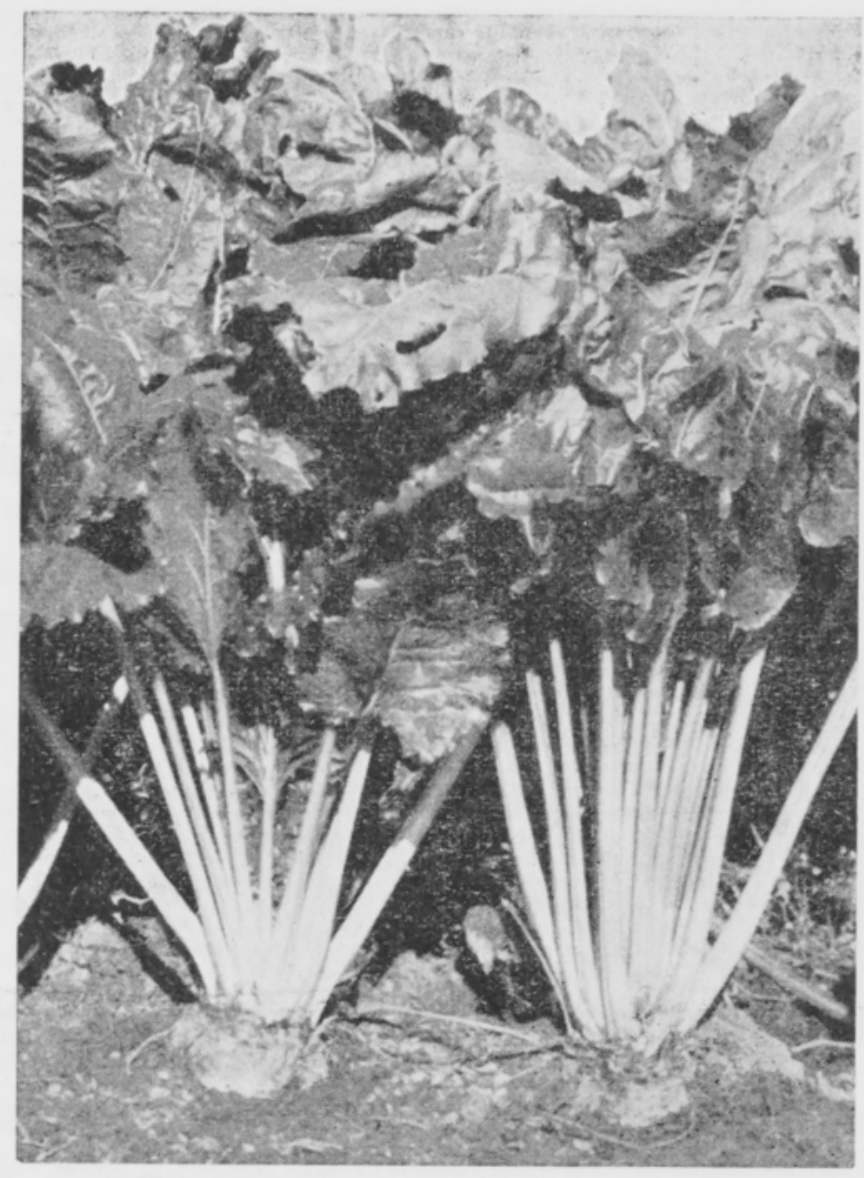

Kuva 2. Suurimman painonsa saavuttanut naatisto syyskuun lopussa. Uusia lehtiä on edelleen kehittymässä. Vanhimpien, kuihtuneiden lehtien arvet näkyvät juuren niskassa.

Abb. 2. Das Kraut in seiner grössten Ausbildung Ende September. Neue Blätter werden immerfort gebildet, am Wurzelhals erblickt man die Narben der ältesten, bereits abgefallenen Blätter.

näytetilojen juurikasmaista on runsas puolet ollut hietamaita. Edellä mainitut Salossa suoritetut kokeet ovat todennäköisesti olleet savimailla.

Jumren paino. Juuren painon kasvu alkaa varsinaisesti vasta heinäkuun alussa. Heinä-elokuun vaihteessa on juuren paino keskimäärin noin 115 g, elo-syyskuun vaihteessa se on ollut noin $260 \mathrm{~g}$, syys-lokakuun vaihteessa noin $360 \mathrm{~g}$. Lokakuun aikana on juurikas edelleen kasvanut noin $12 \mathrm{~g}$ (taul. 4). Keskimäärin on juurikas saavuttanut suurimman painonsa vasta lokakuun loppupuolella niihin aikoihin, jolloin viikkonäytteiden otto yleensä on päättynyt. Painon lisääntyminen lokakuulla on kuitenkin keskimäärin varsin hidasta.

Myöhemmin esitettävän ennakoivan satoarvion perustaksi on otettu juuren keskipaino nostoaikana, millä tarkoitetaan juurikkaan keskipainoa lokakuun ensimmäisellä viikolla. Se on saatu laskemalla syyskuun viimeisen ja lokakuun kahden ensimmäisen viikkonäytteen keskiarvo. Viiden vuoden keskiarvona se on miltei täsmälleen sama kuin lokakuun ensimmäisen viikon (6. 10.) juuren keskipaino, mutta yksittäisinä vuosina se voi jonkinverran poiketa mainitun viikon arvosta ja antanee paremman kuvan juuren keskipainosta nostoaikana kuin yksittäisen viikon keskipaino. 


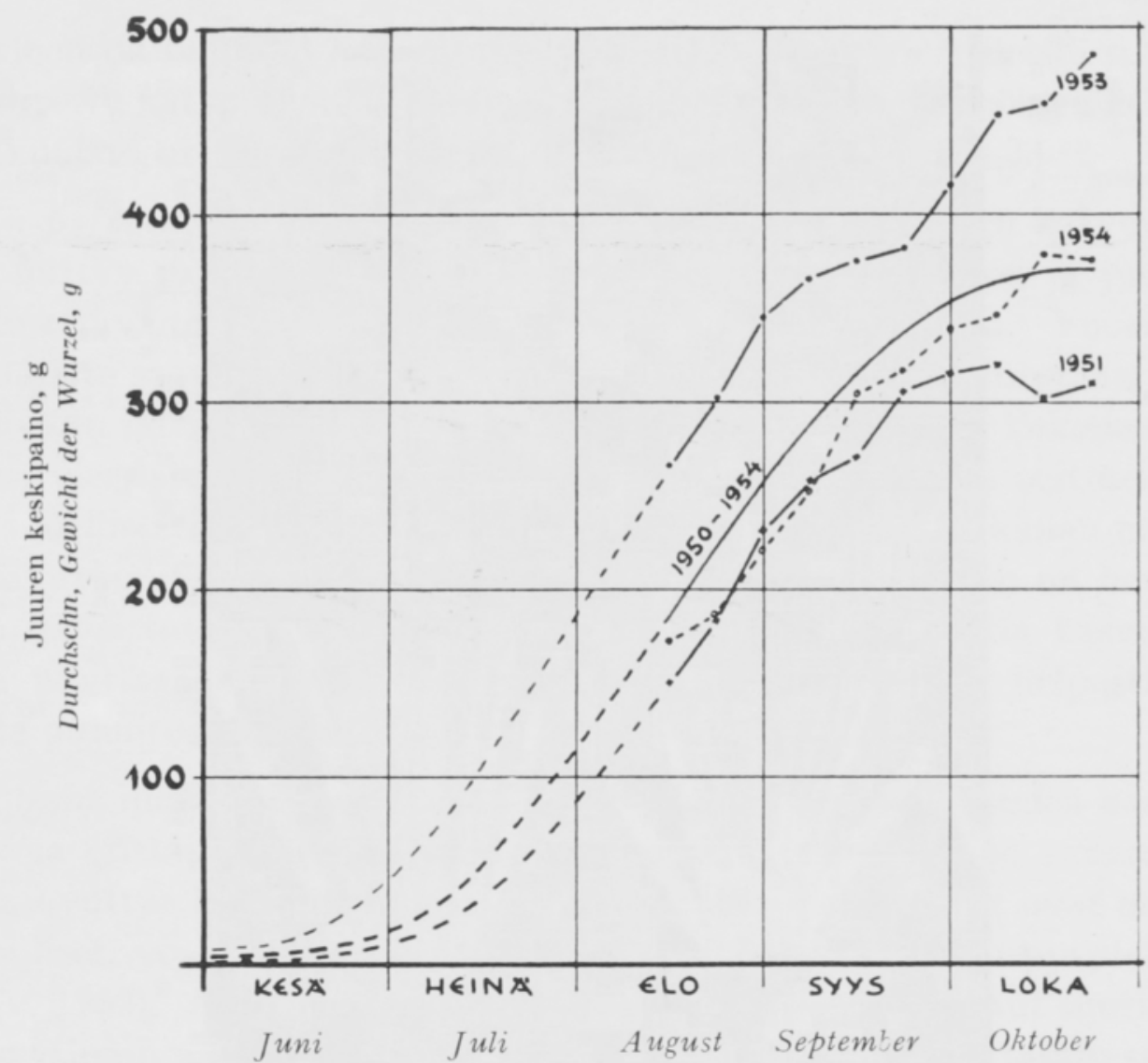

Piirros 2. Juuren painon kehittyminen kasvukausina 1951, 1953 ja 1954 sekä keskimäärin vuosina $1950-1954$

Fig. 2. Entwicklung des Wurzelgewichtes in den Vegetationsperioden der Jahre 1951, 1953 und 1954 sowie durchschnittlich in den Jahren 1950-1954.

1951 kuiva kasvukausi

trockne Vegetationsperiode

1953 aikainen ja edullinen kasvukausi

frühe und günstige Vegetationsperiode

1954 myöhäinen kasvukausi

späte Vegetationsperiode.

Sääsuhteiden vuoksi on sokerijuurikas meillä yleensä nostettava jo lokakuun alkupuoliskolla. Laskien edellä esitetyllä tavalla juuren keskipaino nostoaikana voidaan todeta, että keskimäärin jää meillä juurikkaan kasvutaipumuksesta käyttämättä noin $10 \mathrm{~g}$, mikä vastaa noin 1.000 kiloa hehtaarisadossa, kuten myöhemmin voidaan todeta.

Lämpiminä syksyinä voi lokakuun lisäkasvu kuitenkin olla huomattavasti tavallista suurempi ja pitkäaikaisempi, mikäli samalla on sopivasti kosteutta. Tällainen syksy on ollut nimenomaan v. 1953 ja osittain myös v. 1954. Sensijaan v. 1951, jolloin myös oli lämmin lokakuu, oli kasvu pysähdyksissä ankaran kuivuuden johdosta. Edullisina syksyinä on lokakuun lisäkasvu 20 päivään mennessä ollut jopa $40 \mathrm{~g}$ ja olisi nähtävästi voitu todeta kasvun jatkuvan ainakin lokakuun loppuun asti, jos näytteiden ottoa olisi jatkettu. 
Jos lokakuu on kylmä (v. 1952) tai suunnilleen normaalilämpöinenkin (v. 1950), voi kasvu lokakuussa olla täydellisesti pysähdyksissä, kuten voidaan todeta taulukosta 3. Tällaisena syksynä ei noston lykkäämisestä ole mitään hyötyä.

Tarkasteltavina olevista vuosista ovat kasvukaudet 1951, 1953 ja 1954 eniten keskiarvosta ja toisistaan poikkeavia sekä juurikkaan kasvuedellytysten että myös itse kasvun suhteen. Sokerijuurikkaan juuren painon kehittyminen mainittuina kasvukausina on esitetty piirroksessa 2. Edullisena vuonna 1953 on juuren paino jo elokuun puolivälissä ollut yhtä suuri kuin vuosina 1951 ja 1954 noin 3 viikkoa myöhäisempänä ajankohtana. Grammamääräinen lisäkasvu näytteiden oton alkamisen ajankohdasta (18. 8.) lähtien nostoaikaan mennessä on edullisena kasvukautena 1953 ollut miltei täsmälleen viiden vuoden 1950-54 keskiarvoa vastaava eli $176 \mathrm{~g}$. Ankaran kuivuuden ahdistamana kasvukautena 1951 on vastaava lisäkasvu ollut pienempi eli $163 \mathrm{~g}$. Lähinnä kasvukauden alkamisen myöhästymisestä johtuen oli juuren paino elokuussa 1954 vain v. 1951 tasolla, mutta kasvu jatkui syyskuulla keskimääräistä nopeammin ja lisäkasvua saatiin nostoaikaan mennessä $183 \mathrm{~g}$. Todennäköisempi arvo olisi kuitenkin noin $200 \mathrm{~g}$, koska ensimmäisen näytteenottokerran antama juuren keskipaino todennäköisesti on liian korkea. Itse asiassa ovat erot grammamääräisessä kasvussa kasvukauden loppupuolella eri vuosina suhteellisen vähäisiä verrattuna niihin eroihin, mitä juuren kasvussa eri vuosina jo elokuun puoleen väliin mennessä on ilmennyt. Kun juuren keskipaino mainittuna ajankohtana v. 1951 ja myös v. 1954 oli noin 150 g, oli se edellisenä vuonna vastaavana aikana kokonaista $268 \mathrm{~g}$. Ero kasvukauden alkupuoliskon kasvussa on siis ollut 110 120 g. Kun erot kasvukauden jälkipuoliskolla tapahtuvassa lisäkasvussa ovat eri vuosina olleet korkeintaan vain muutamia kymmeniä grammoja, voimme todeta, että saatavan juurikassadon määrän ratkaisee pääosaltaan jo kasvukauden alkupuoliskon aikana tapahtunut kehitys. Tämä on omiansa vahvistamaan sitä vanhaa käsitystä että kevätpäivä vastaa sokerijuurikkaalla useampaa syksyn päivää.

\section{Sokeripitoisuuden kehittyminen}

Juurikkaan sokeripitoisuuteen on sääsuhteilla vielä huomattavasti tuntuvampi vaikutus kuin juuren kasvuun. Taulukossa 5 esitetään sokeripitoisuuden kehitys eri vuesina.

Alhainen lämpötila, pilvisyys ja runsas sademäärä yhdessä voivat aiheuttaa sen, että juurikkaan sokeripitoisuuden nousu pysähtyy jo normaalia aikaisemmin ja polarisatio jää alhaiseksi. Tyypillinen esimerkki tällaisesta kasvukaudesta on v. 1952. Syyskuun kolmannen viikon jälkeen on sokeripitoisuus jo alkanut hiljalleen laskea yhteyttämistoiminnan ollessa hidasta ja juurikkaan imiessä vettä. Vuonna 1953 ei vastaavanlaista ilmiötä esiinny, vaikka sademäärät olivatkin suunnilleen yhtä suuret. Lämpötilan pysytellessä normaalina jatkui polarisation nousu normaaliin tapaan. Myöhään alkaneena kasvukautena 1954 oli juurikkaiden sokeripitoisuus tutkimuksen alkaessa erittäin alhainen. Polarisation nousu jatkui kuitenkin hyvin suoraviivaisesti koko tutkimuksen ajan, niin että nostoaikaan mennessä 
Taulukko 5. Viikkonäytteiden polarisatio eri vuosina

Tabelle 5. Durchschnittliche Polarisation der Wocheproben in den einzelnen Jahren.

\begin{tabular}{|c|c|c|c|c|c|c|c|c|c|c|}
\hline $\begin{array}{c}\text { Viikko } \\
\text { Woche }\end{array}$ & I & II & III & IV & V & VI & VII & VIII & IX & X \\
\hline 1950 & 14.0 & 14.5 & 15.2 & 15.3 & 15.6 & 15.3 & 15.9 & 16.1 & 16.3 & 16.6 \\
1951 & 13.0 & 14.2 & 14.3 & 15.4 & 16.6 & 16.5 & 16.8 & 17.5 & 17.9 & 18.4 \\
1952 & 10.7 & 12.2 & 12.0 & 13.2 & 15.0 & 15.4 & 15.2 & 15.1 & 15.0 & 15.9 \\
1953 & 12.8 & 12.8 & 13.5 & 14.5 & 15.7 & 16.2 & 16.0 & 16.7 & 16.7 & 16.6 \\
1954 & 8.6 & 10.6 & 11.6 & 12.1 & 13.2 & 14.1 & 15.2 & 15.6 & 16.2 & 16.5 \\
\hline $1950-54$ & 11.8 & 12.9 & 13.3 & 14.1 & 15.2 & 15.5 & 15.8 & 16.2 & 16.4 & 16.8 \\
\hline
\end{tabular}

päästiin melko lähelle keskimääräistä tasoa. Kuivuuden vaivaamana kasvukautena 1951, jolloin juuren painon kasvu oli hidasta, kohosi sokeripitoisuus poikkeuksellisen korkealle.

Viiden sangen erilaisen vuoden keskiarvotulosten mukaan lisääntyy juurikkaiden sokeripitoisuus koko käytettävissä olevan kasvukauden ajan. Polarisation nousu on nopeinta heinä-elokuulla, mutta vielä syyskuullakin lisääntyy sokeripitoisuus juurikkaissa viikoittain keskimäärin noin $0.5-0.8 \%$ (piirros 1). Lokakuulla nousu jo on huomattavasti hidastunut, mutta näyttää keskimäärin jatkuvan vielä sen ajan ylikin, jolloin näytteiden otto on lopetettu (20. 10.).

Usein esitetään, että sokeria kertyy sokerijuurikkaan juureen - juurikkaan sokeripitoisuus nousee - pääasiassa vasta kasvukauden loppupuolella. Polarisation nousu on kuitenkin nopeinta kasvukauden alkupuolella, kuten todettiin, ja hidastuu vähitellen syys-lokakuulla. Kiintoista on tarkastella sitä sokerimäärää, minkä sokerijuurikas keskiarvotulosten mukaan viikoittain varastoi juureensa kasvukauden eri vaiheissa. Jos otetaan keskimääräiset juuren painot ja polarisatiot kuviossa 1 esitetyiltä käyriltä, jolloin saadaan todennäköiset, sattumanvaraisista heilahteluista vapaat arvot, voidaan laskea juurikkaaseen keskimäärin eri viikkoina varastoituva sokerimäärä.

\begin{tabular}{|c|c|c|c|c|}
\hline Viikko & $\begin{array}{l}\text { Tasoitettu } \\
\text { juuren paino } \\
\mathrm{g}\end{array}$ & $\begin{array}{c}\text { Tasoitettu } \\
\text { polarisatio } \\
\%\end{array}$ & $\begin{array}{l}\text { Juuren sis. } \\
\text { sokerimäärä } \\
\mathrm{g}\end{array}$ & $\begin{array}{l}\text { Pol. sokerin } \\
\text { lisäys } \\
\text { g }\end{array}$ \\
\hline I (18. 8.) & 185 & 11.5 & 21.3 & - \\
\hline II (25. 8.) & 222 & 12.6 & 28.0 & +6.7 \\
\hline III ( 1.9.$)$ & 256 & 13.5 & 34.6 & +6.6 \\
\hline IV ( 8. 9.) & 288 & 14.2 & 40.9 & +6.3 \\
\hline $\mathrm{V}\left(\begin{array}{ll}15 . & 9 .\end{array}\right)$ & 317 & 14.9 & 47.2 & +6.3 \\
\hline VI (22. 9.) & 340 & 15.5 & 52.7 & +5.5 \\
\hline VII (29. 9.) & 355 & 15.9 & 56.5 & +3.8 \\
\hline VIII ( 6.10.$)$ & 364 & 16.2 & 59.0 & +2.5 \\
\hline IX (13. 10.) & 370 & 16.5 & 61.1 & +2.0 \\
\hline $\mathrm{X}(20.10)$. & 372 & 16.7 & 62.1 & +1.0 \\
\hline
\end{tabular}


Keskimääräistä kokoa olevaan sokerijuurikkaaseen varastoituu elokuun puoliväliin mennessä eli pääasiassa noin 6 viikon aikana sokeria kaikkiaan noin $20 \mathrm{~g}$. Kun tarkastetaan sokerimäärän lisääntymistä seuraavina viikkoina voidaan todeta, että sokerin varastoituminen juureen ja todennäköisesti myös sen valmistuminen lehdistössä on vilkkaimmillaan elokuun puolivälistä syyskuun puoliväliin ollen noin $6.5 \mathrm{~g}$ viikossa. Myöhemmin viikoittain varastoituva sokerimäärä vähitellen laskee ja on lokakuun alkuviikkoina keskimäärin noin $2 \mathrm{~g}$ viikossa. Sokerin varastoituminen juureen ei siis ole suurimmillaan aivan kasvukauden lopussa, vaan jo elo-syyskuun vaihteessa. On kuitenkin syytä todeta, että keskimääräisesti on juurikkaan naatisto hyvin toimintakykyinen vielä lokakuun alkupuolellakin, koska juurikkaan sokerimäärä edelleen lisääntyy ja myös itse juurikas jonkinverran kasvaa.

Juurikkaan polarisation nousulla vielä kasvukauden lopulla on varsin suuri merkitys, koska juurikkaasta saadaan tehtaassa sokeria suhteellisesti sitä enemmän, mitä korkeampi on juurikkaiden sokeripitoisuus (1). Valitettavasti ei tätä lokakuussa tapahtuvaa sokeripitoisuuden nousua meidän ilmastossamme ehditä täysin käyttää hyväksi, vaan nosto on pakko suorittaa jonkinverran ennenaikaisesti. Esimerkiksi Saksassa kohoaa sekä juurikkaan paino että sokeripitoisuus korkeimmilleen jo lokakuun lopussa (3) ja nostokautta jatkuu huomattavasti pidemmälle kuin meillä.

\section{Odotettavissa olevan sadon arvioiminen}

Edellä todettiin, että sokerijuurikkaan juuren kasvun erilaisuus eri vuosina ilmenee selvästi jo kasvukauden alkupuoliskolla. Jälkipuoliskon aikana kasvu sensijaan noudattelee eri vuosina melko kiinteästi samoja latuja. Tiettyjä poikkeuksia voi kuitenkin esiintyä. Korkea lämpötila kasvukauden lopulla edistää juuren kasvua. Jos kuitenkin alkukehitys on jo ollut keskimääräistä parempi, ei kasvukauden lopulla enää ole odotettavissa poikkeuksellisen hyvää lisäkasvua. Keskimääräistä parempi lisäkasvu kasvukauden lopulla voidaan todennäköisesti saada sellaisena vuonna, jolloin kylvö on myöhästynyt ja juuren painon kehitys siten on normaalirytmistä jäljessä. Keskimääräistä heikompi lisäkasvu voi aiheutua mm. liian alhaisesta lämpötilasta tai kuivuudesta kasvukauden lopulla. Pitkälle menevien johtopäätösten tekoon on aineistoa toistaiseksi liian lyhyeltä ajalta.

Esitettyjen tulosten ja havaintojen mukaisesti on ilmeistä, että viimeistään syyskuun alussa voidaan tehdä jotenkin luotettavia päätelmiä siitä, minkälaiseksi juurikkaan keskipaino nostoaikana tulee muodostumaan. Mahdollisesti voitaisiin päätelmiä tehdä jo aikaisemminkin, mikäli näytteiden otto aloitettaisiin aikaisemmin. Oikean lähtökohdan saamiseksi on ainakin kahden näytteenottokerran tulokset hyvä olla käytettävissä, jotta mahdolliset satunnaiset virheet eivät pääsisi tulokseen vaikuttamaan. Taulukossa 6 on esitetty juurikkaan keskipaino syyskuun alussa ja lisäkasvu nostoaikaan mennessä keskimäärin vv. 1950-54 sekä eniten normaalista poikkeavina vuosina.

Kuten aikaisemmin esitettiin, alkaa sokerijuurikkaan juuren kasvu vasta heinäkuun alussa, mutta elokuun loppuun mennessä on juurikas keskimäärin saanut jo 
Taulukko 6. Juuren keskipaino 1. 9. sekä todettu lisäkasvu nostoaikaan mennessä viitenä vuotena keskimäärin ja eräinä eniten poikkeuksellisina vuosina.

Tabelle 6. Durchschnittliches Gewicht der Wurzel am 1. 9. und festgestellter Zuwachs bis zur Erntezeit durchschnittlich in den Jahren 1950-1954 und in den meist abweichenden Jahren dieser Periode.

\begin{tabular}{|c|c|c|c|}
\hline & $\begin{array}{c}\text { Juuren keskipaino } \\
\text { Durchschn. Wurzelgewicht } \\
\text { 1. } 9 . \\
\text { g }\end{array}$ & $\begin{array}{l}\text { Juuren keskipaino } \\
\text { nostoaikana } \mathrm{g} \\
\text { Gewicht zur Ernte- } \\
\text { zeit } \mathrm{g}\end{array}$ & $\begin{array}{l}\text { Lisäkasvu } g \\
\text { Zuwachs } g \\
\text { 1. } 9-6.10 .\end{array}$ \\
\hline $\begin{array}{l}\text { Keskimäärin } 1950-1954 \\
\text { Durchschn. 1950-1954 }\end{array}$ & 262 & 363 & 101 \\
\hline $\begin{array}{l}\text { Kuiva vuosi } 1951 \\
\text { Im trocknen Jahr } 1951\end{array}$ & 232 & 312 & 80 \\
\hline $\begin{array}{l}\text { Edullinen vuosi } 1953 \\
\text { In gü̈nstigen Jahr } 1953\end{array}$ & 346 & 444 & 98 \\
\hline $\begin{array}{l}\text { Myöhäinen vuosi } 1954 \\
\text { Im späten Jahr } 1954\end{array}$ & 222 & 355 & 133 \\
\hline
\end{tabular}

noin $70 \%$ lopullisesta painostaan (taul. 4). Eri vuosina voi kuitenkin ilmetä suuria poikkeuksia.

Lisäkasvu syyskuun alusta nostoaikaan mennessä on ollut keskimäärin $101 \mathrm{~g}$, erittäin ankaran kuivuuden vallitessa v. 1951 vastaavasti 80 g ja myöhäisenä, lämpimänä syksynä 1954 noin 130 g. Näiden äärimmäisten tapausten erotus juuren lisäkasvussa syyskuun alusta lähtien on siis $50 \mathrm{~g}$.

Millaiseksi juurikkaan keskipaino nostoaikaan mennessä todennäköisesti muodostuu, voidaan elo-syyskuun vaihteessa arvioida lisäämällä silloin todettuun juuren keskipainoon pyöreästi $100 \mathrm{~g}$, elleivät erikoiset seikat anna aihetta pienentää tai suurentaa odotettavissa olevan lisäkasvun määrää. Tällöin on otettava huomioon mm. kasvukauden alkamisen ajankohta siihen tapaan kuin aikaisemmin on esitetty. Suurin vaikutus on kuitenkin todennäköisesti sääsuhteilla eikä niiden ennustaminen riittävän pitkällä tähtäimellä ole mahdollista.

Kehityksen jatkuessa siten, että juurikasmaiden kasvukunto edelleen parantuu ja juurikkaan kasvutaipumus meikäläisissä oloissa myös jalostustyön tuloksena lisääntyy, vanhentuvat edellä esitetyt keskimääräiset arvot vähitellen. Kehityksen mukana pysytään kuitenkin yksinkertaisesti siten, että kasvututkimuksia suoritetaan jatkuvasti vuodesta toiseen.

On selvää, että edellä esitettyjä lukuja voidaan sellaisenaan varmuudella käyttää vain Turengin tehtaan viljelyalueella, koska materiaali on kerätty Hämeen ja Uudenmaan juurikasmailta. Tässä yhteydessä on syytä todeta, että eri vuosina tehtyjen vertailujen mukaan ovat ne maatilat, joilta viikkonäytteitä on otettu, tuottaneet noin 5-10\% parempia juurikassatoja kuin mitä keskimäärin saadaan Turengin tehtaan alueella. Esitetyt juurikkaan kasvuarvot ovat siis todennäköisesti hieman nykyistä Hämeen ja Uudenmaan keskitasoa parempia. 


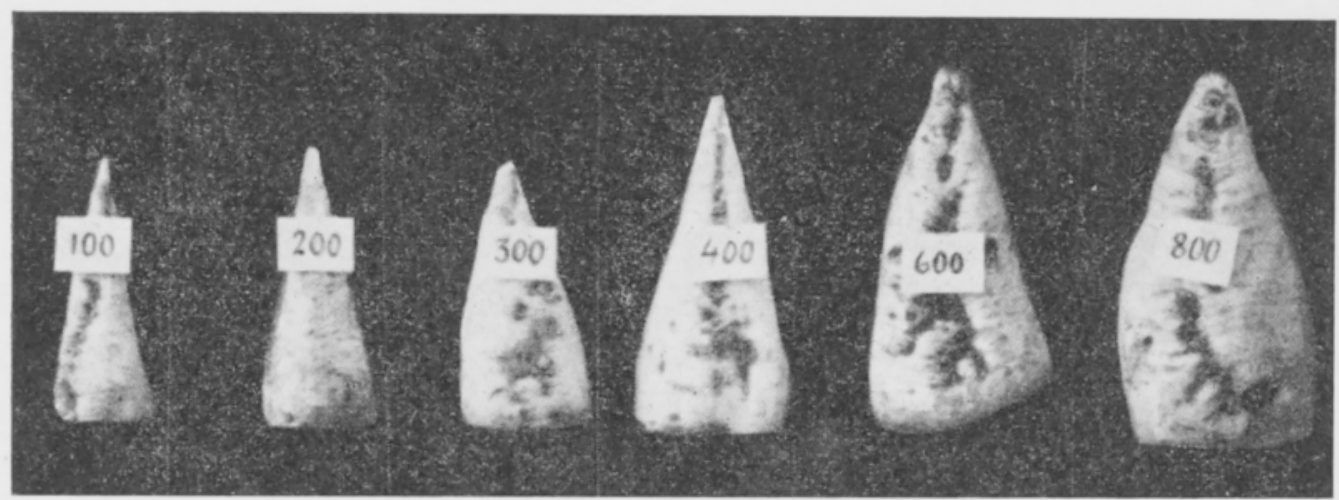

Kuva 3. Eri painoisia juurikkaita kasvukauden lopulla. (Painot grammoina).

Abb. 3. Verschieden grosse Rüben am Ende der Vegetationsperiode. (Gewichte in g.).

\section{Junrikkaan keskipaino ja hehtaarisato}

Teoreettisesti on laskettavissa, että jonkin juurikasmaan tuottama hehtaarisato saadaan kertomalla juurikkaan keskimääräinen paino nostoaikana niiden juurikkaiden lukumäärällä, jotka hehtaarin alalla ovat kasvamassa. Yksilölukuna on tällöin pakko käyttää kentällä suoritetun taimilaskennan tulosta. Käytäntö osoittaa, että näin laskien saadaan aina huomattavasti liian korkeita satoarvioita. Tällaiseen tulokseen on vaikuttamassa useitakin syitä. Ruotsissa on todettu (5), että kentällä laskettu yksilöluku on keskimäärin noin 5-15\% suurempi kuin todella hehtaarin alalta syksyllä tehtaalle luovutettujen juurikkaiden lukumäärä. Tämän eron voi olettaa johtuvan taimiston harventumisesta keskinäisen kilpailun tuloksena vielä kasvukauden loppupuolellakin ja myös siitä, että nostossa ei suinkaan kaikkia juurikkaita saada talteen. Nimenomaan pieniä juurikkaita jää maahan tai naattien joukkoon pellolle.

Käytännön tulokset osoittavat, että virheellisin satoarvio taimiluvun perusteella laskien saadaan silloin, kun juurikkaan keskipaino on pieni, mikä puolestaan viittaisi juuri pienien juurikkaiden katoamiseen korjuun yhteydessä.

Kun yritetään arvioida koko tehtaan viljelyalueen keskisatoa viikkonäytteiden tuloksista saadun juurikkaan keskipainon perusteella, tulee huomattavana virhetekijänä laskelmiin mukaan näytemaatilojen enemmän tai vähemmän heikko edustavuus. Nimenomaan silloin, kun juurikkaanviljely on jollain alueella kehitystilassa, ovat olosuhteet ja myös satotulokset suuresti toisistaan poikkeavia. Tällaisesta heterogeenisesta joukosta on miltei mahdoton saada täysin edustavaa aineistoa. Kuten jo aikaisemmin esitettiin, on näytetilojen Turengin tehtaan alueella todettu tuottavan noin 5-10\% keskimääräistä satoa parempia juurikassatoja.

Erilaisten virhetekijöiden voidaan kuitenkin olettaa pysyvän vuodesta toiseen suunnilleen samanlaisina. Taimiluvun vaikutusta selvittelevien tutkimusten mukaan on mm. todettu, että keskimääräinen yksilöluku niin näytetiloilla kuin yleensäkin juurikasmailla riittävän suuren aineiston perusteella keskimäärin laskien vaihtelee vuodesta toiseen niin vähän, että sen vaikutus keskimääräiseen hehtaarisatoon voi olla vain pari kolme prosenttia. 


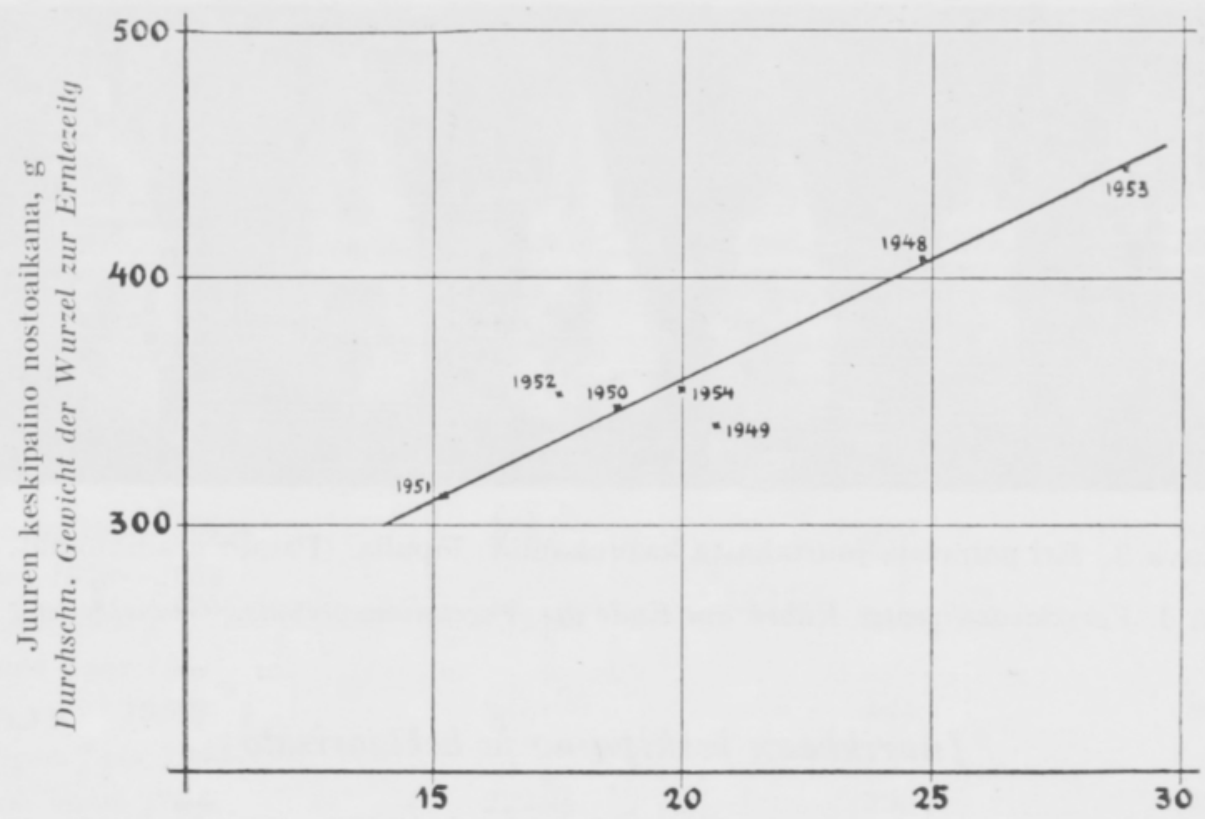

Turengin tehtaan viljelyalueen keskisato tonnia ha

Durchschn. Rübenernte $t / h a$

Piirros 3. Hehtaarikeskisatojen riippuvaisuus juuren keskipainosta nostoaikana.

Fig. 3. Abhängigkeit der durchschnittlichen Hektarerträge vom mittleven Wurzelgewicht zur E rntezeit.

Odotettavissa olevan keskisadon arvioimiseksi viikkonäytteiden antamien tulosten perusteella kehitettiin kesällä 1954 seuraava yksinkertainen menetelmä. Kasvututkimusten perusteella saatua juurikkaan keskipainoa nostoaikana vastaa kunakin vuonna tietty tehtaan viljelyalueen keskisato. Kun eri vuosien tuloksia verrataan toisiinsa havaitaan, että on olemassa ilmeinen riippuvaisuussuhde nostoaikana todetun juurikkaan keskipainon ja saadun keskihehtaarisadon välillä. Aikaisemmin esitetyn mukaisesti voidaan jo elokuun lopussa melko hyvin perustein arvioida, millaiseksi juurikkaan keskipaino nostoaikaan mennessä muodostuu. Tätä arviota voidaan kasvukauden edelleen jatkuessa tarpeen mukaan korjata.

Juurikkaan keskipaino nostoaikana eri vuosina ja vastaavat keskihehtaarisadot on esitetty seuraavassa asetelmassa. Siihen on otettu myös vuosien 1948 ja 1949 tulokset, koska näiltäkin vuosilta on olemassa viikkonäytteiden tuloksia juurikkaan keskipainosta nostoaikana.

Vuosi

1950

1951

1952

1953

1954

Juurikkaan keskipaino nostoaikana

(408) $(340)$

348

312

353

444

355

Keskisato tn/ha

18.7

15.2

$17.5 \quad 28.9$

20.0

Asettamalla vastaavat arvot koordinaatistolle voidaan piirtää juurikkaan keskipainon ja keskihehtaarisadon välistä riippuvaisuussuhdetta esittävä kuvaaja (piirros 3). Havaintopisteiden perusteella piirrettävissä oleva kuvaaja on suora, jonka asento koordinaatistossa on sellainen, että juurikkaan keskipainon lisääntyessä sato lisääntyy suhteellisesti huomattavasti enemmän. Saadun kuvaajan yhtälö on: 
$\mathrm{s}=0.101 \times \mathrm{p}-16.3$, jossa $\mathrm{s}=$ keskihehtaarisato tonneina ja $\mathrm{p}=$ juurikkaan keskipaino g nostoaikana.

Määrittelemällä edellä esitettyyn tapaan elokuussa todettujen viikottaisten keskipainojen ja odotettavissa olevan keskimääräisen lisäkasvun perusteella, mikä juurikkaan keskipaino tulee olemaan nostoaikana, voidaan odotettavissa oleva keskihehtaarisato laskea yhtälöstä. Todennäköisesti on mahdollisuus käyttää yhtälöä vain juurikkaan keskipainon ollessa 300 g yläpuolella, niinkuin se lokakuun alussa on heikoimpanakin satovuonna ollut. Juuren keskipainon ja keskihehtaarisadon riippuvaisuussuhdetta osoittava kuvaaja ei ilmeisesti ole alkupäästään suora, vaan käyrä, joka kulkee origon kautta. Tällä seikalla ei kuitenkaan tässä yhteydessä ole merkitystä.

Laskemalla vuosien 1948-1954 keskisadot juurikkaan keskipainon perusteella edellä esitettyä yhtälöä käyttäen saadaan seuraavat tulokset:

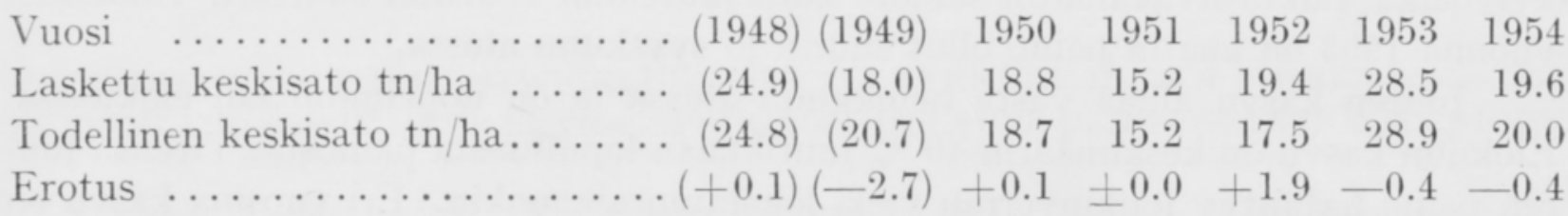

Kaikkina muina vuosina paitsi vuonna 1949 ja 1952 on yhtälöä käyttäen juurikkaan keskipainon perusteella laskettu sato varsin yhtäpitävä todellisen keski-hehtaarisadon kanssa. Vuoden 1952 osalta ovat ilmeisesti vaikuttamassa erittäin vaikeat korjuuolosuhteet. On todennäköistä, että maahan ja lumen alle jääneiden juurikkaiden johdosta korjuutappiot muodostuivat merkittävän suuriksi. Keväällä 1953 paljastuneilla juurikasmailla näkyi harvinaisen runsaasti maahan jääneitä juurikkaita. Odotettua heikompi sato on ainakin osittain täten ymmärrettävissä. Vuonna 1949 saadaan juurikkaan keskipainon perusteella laskien huomattavasti liian pieni sato. Mistä tämä johtuu, on vaikeasti selitettävissä. Näytetiloja on ollut vain parikymmentä, joten virhemahdollisuudet juurikkaan keskipainon määrittämisessä ovat todennäköisesti olleet varsin suuret.

Jos vuosi 1949 jätetään pois, on suurin virhe (1952) noin $10 \%$ lasketusta keskisadosta. Kuten muiden vuosien tulokset osoittavat, voidaan yleensä saavuttaa huomattavasti suurempi tarkkuus silloin, kun juurikkaan todellinen keskipaino jo on tiedossa. Mitä aikaisemmassa vaiheessa yritetään arvioida, minkälaiseksi juurikkaan keskipaino nostoaikana muodostuu, sitä epävarmempana on saatua tulosta luonnollisesti pidettävä. Ehdottomaan tarkkuuteen tuskin koskaan päästään, vaikka olisi käytettävissä tulokset hyvinkin monelta vuodelta, sillä 10 g ero juurikkaan keskipainossa merkitsee noin 1000 kilon eroa hehtaarisadossa. Kun juuren kasvu on sääsuhteista riippuvainen, voi tällaisia eroja aina odottamattakin ilmetä.

Luonnollisesti olisi myös mahdollista johtaa yksinkertainen yhtälö tulevan sadon laskemiseksi suoraan esimerkiksi 1. 9. todetun juurikkaan keskipainon mukaan, mutta tällöin ei voitaisi ottaa huomioon lisäkasvussa mahdollisesti odotettavissa olevia poikkeamia keskiarvosta. Arvioimalla juuren painon kehitys nostoaikaan mennessä edellä esitettyyn tapaan päästään todennäköisesti ainakin yhtä hyvään tulokseen kuin puhtaasti matemaattisella menettelyllä. 


\section{Yhteenveto}

Sokerijuurikkaan juuren ja naatin kasvua sekä sokeripitoisuuden kehittymistä kasvukausien 1950 - 1954 aikana on seurattu juurikasmailta viikoittain otettujen näytteiden perusteella. Näytetiloja on valittu yhtä paljon kustakin Turengin Sokeritehtaan viljelyalueen neuvontapiiristä. Kolmena viimeksi kuluneena vuonna on näitä tiloja ollut vuosittain yhteensä 90 tai enemmän.

Näytteiden ottaminen tietyn järjestelmän mukaisesti, jolloin subjektiivinen valinnan mahdollisuus jää pois, antaa parhaan tuloksen. 20 juurikasta kussakin näytteessä on todennäköisesti riittävä silloin, kun näytteitä otetaan yhteensä useita kymmeniä.

Sokerijuurikkaan naatti kehittyy harvennuksen jälkeen hyvin nopeasti. Korkeimmillaan on naatin paino keskimäärin syyskuun lopussa. Sääsuhteet ja myös kylvöaika vaikuttavat naatin samoin kuin juurenkin kasvuun suuresti. Aikaisena vuonna 1953 on naatin paino ollut suurin jo syyskuun alussa.

Juuren kasvu alkaa vasta heinäkuun alussa ja on nopeimmillaan elokuussa. Elokuun kasvu on keskimäärin $40 \%$ juurikkaan lopullisesta painosta. Yleensä juuren paino lisääntyy jonkinverran vielä lokakuun aikanakin. Eri vuosina kasvu on erilaista, nimenomaan kasvukauden alkupuoliskolla. Jo tällöin tulee varsinaisesti ratkaistuksi, millaiseksi juurikkaan keskipaino muodostuu. Juuren lisäkasvu syyskuun alusta nostoaikaan mennessä on ollut keskimäärin noin 100 grammaa.

Nostoajan keskiarvopaino on laskettu syyskuun lopussa ja lokakuun kahden ensimmäisen viikon aikana otettujen viikkonäytteitten mukaan.

Sokeripitoisuuden kehittymiseen vaikuttavat sääolosuhteet ratkaisevasti. Keskimäärin eri vuosina lisääntyy juurikkaan sokeripitoisuus vähitellen hidastuen koko kasvukauden ajan. Vilkkaimmillaan on sokerin varastoituminen juureen elokuun lopulla ja syyskuun alkuviikkojen aikana. Juurikkaan kykyä tuottaa sokeria ei ilmastossamme voida täydellisesti käyttää hyväksi, koska nosto on yleensä saatava suoritetuksi loppuun jonkinverran ennenaikaisesti.

Kun suurimmat eroavaisuudet juurikkaan kasvussa ilmenevät jo kasvukauden alkupuoliskolla, on mahdollista laskelmoida elokuun lopussa saatujen viikottaisten punnitustulosten ja keskimääräisen lisäkasvun perusteella, millainen juurikkaan keskipaino tulee nostoaikana olemaan. Tämän keskipainon suuruudesta riippuu saatavan juurikassadon suuruus. Tutkimustulosten mukaisesti on päädytty kaavaan, jota käyttäen odotettavissa oleva hehtaarikeskisato voidaan laskea näytejuurikkaiden keskipainon perusteella. 


\title{
KIRJALLISUUTTA
}

(1) Asche, Тн. 1950. Der Einfluss des Zuckergehalts in der Zuckerrüben bei der Verarbeitung auf Zucker. Zucker, Z. für Zuckerrübenbau-Zuckerindustrie-Hefeindustrie, p. 238-240.

(2) Ehnrot, Boris, 1945. Skördeuppskattningar. Socker, Svenska Sockerfabriks AB skrifter, Meddel. 22. p. 887-912. Malmö.

(3) LÜDECKE, Hans, 1953. Zuckerrübenbau. Hamburg.

(4) Mantere, Martti, 1954. Sokerijuurikaskantojen aikaisuuden vertailu. Maataloustiet. Aikak. 3, p. $130-141$.

(5) Åstrand, Halvdan, 1948. Plantantalet i sockerbetsfälten. Odlaremeddel. 20 från Svenska Sockerfabriks AB, p. 1-8. Arlöv.

(6) Kuukausikatsaus Suomen sääoloihin, vuodet $1950-1954$.

\section{REFERAT:}

ÜBER DIE WACHSTUMSENTWICKLUNG DER ZUCKERRÜBE IN DEN JAHREN 1950-1954 IN FINNLAND SOWIE ÜBER ERTRAGSPROGNOSE IM LAUFE DER VEGETATIONSPERIODE

\author{
Aimo Kaivola
}

\section{Zuckerfabrik Turenki AG, Turenki.}

Im Anbaugebiet der Zuckerfabrik Turenki wurde in den Jahren 1950-1954 auf Grund wöchentlicher Rübenuntersuchungen das Wachstum von Wurzel und Kraut sowie die Entwicklung des Zuckergehalts der Rüben im Laufe der Vegetationsperiode verfolgt.

Das Blattgewicht der Zuckerrübe erreicht seinen Höchstwert in Finnland durchschnittlich Ende September. Die Witterungsverhältnisse und auch die Zeit der Aussaat beeinflussen stark das Wachstum des Krautes wie auch der Wurzel. Im Jahr 1953, als die Vegetationsperiode schon früh einsetzte, wurde das Gewichtsmaximum des Krautes schon Anfang September erreicht.

Der eigentliche Grössenzuwachs der Wurzel beginnt erst Anfang Juli und ist im August am intensivsten. In diesem Monat werden durchschnittlich $40 \%$ vom endgültigen Gewicht der Rübe angelegt. Im allgemeinen nimmt das Gewicht der Wurzel noch im Oktober etwas zu. In warmen Herbsten könnte dieser Zuwachs eine nicht geringe Ertragssteigerung herbeiführen, unter den hiesigen Klimaverhältnissen kann er aber nicht voll ausgenutzt werden. Die Unterschiede im jährlichen Wachstum geben sich schon in der ersten Hälfte der Vegetationsperiode zu erkennen, indem bereits dieser Zeitpunkt massgebend dafür ist, wie sich das durchschnittliche Gewicht der Rüben gestalten wird. Von Anfang September bis zur Ernte hat die Wurzel durchschnittlich um etwa 100 Gramm zugenommen.

Das durchschnittliche Erntegewicht der Rüben wurde an Wochenproben aus der letzten Septemberwoche und den zwei ersten Oktoberwochen bestimmt, weil die Zuckerrübe in Finnland meistens schon in der ersten Oktoberhälfte geerntet werden muss.

Für die Entwicklung des Zuckergehalts sind die Witterungsverhältnisse von entscheidender Bedeutung. Im Gesamtdurchschnitt betrachtet, nimmt der Zuckergehalt der Rübe, langsam abklingend, während der ganzen Vegetationsperiode zu. Am lebhaftesten ist die Einlagerung von Zucker in der Wurzel Ende August und während der ersten Septemberwochen.

In Anbetracht dessen, dass die grössten Unterschiede im jährlichen Wachstum der Zuckerrübe schon in den durchschnittlichen Gewichtswerten für Ende August hervortreten, lässt sich das mutmassliche mittlere Erntegewicht der Wurzel vorausberechnen. Die Untersuchungen haben zu der Aufstellung einer einfachen Formel geführt, mit deren Hilfe sich der zu erwartende durchschnittliche Hektarertrag auf Grund des mittleren Gewichtes der Proberüben berechnen lässt. 